\title{
PKS’ DEMOCRATIC EXPERIENCES IN RECRUITING MEMBERS AND LEADERS
}

\author{
Ahmad Ali Nurdin \\ Sunan Gunung Jati State Islamic University, Bandung, Indonesia
}

\section{Abstract:}

This paper focuses on the views of democracy and the implementation of democratic rules in real politics by the Islamic political party that has a democracy platform in Indonesia, Partai Keadilan Sejabtera (PKS). I examine $P K S$ views on the relationship between Islam and democracy and its manner of recruiting members and leaders to show that this Islamic political party is not a threat to democracy at all. PKS believes that democracy goes to the roots of Islam and the Indonesian context in which they exist; and that it is a good political tool for an Islamic party like PKS to achieve its political goals. Taking the process of recruitment of members and leaders of PKS as examples, the paper also shows that the commitment of PKS to strengthening democracy in Indonesia could be seen in theirprocess of recruiting leaders. PKS has practiced democratic rules in their internal party activities, particularly in the way they used to recruit their members who would be nominated as parliamentary members and how they choose their own leaders. However, it is necessary to note that in terms of member recruitment and expanding the cadres of the party, the PKS seems to have a special strategy; that is, encouraging their cadres to have big families.

[Artikel mengulas pandangan Partai Keadilan Sejabtera (PKS) mengenai demokrasi dan implementasi nilai-nilai demokrasi dalam kehidupan politik. Dalam artikel ini, relasi Islam dan demokrasi serta metode PKS dalam merekrut anggota dan pemimpin partai akan dibahas. PKS sama sekali bukanlah ancaman bagi demokrasi. PKS percaya bahwa prinsip demokrasi 
dapat ditemukan dalam Islam dan konteks Indonesia. Bagi PKS, demokrasi membuka ruang kesempatan bagi partai politik. Islam untuk mencapai tujuan politiknya. Selain itu, artikel ini juga mengulas proses rekrutmen anggota dan pemimpin partai. Rekrutmen petinggi PKS memperlibatkan komitmen PKS terbadap penguatan demokrasi di Indonesia. PKS sudah mempraktekkan prinsip demokrasi dalam tubuh partai, utamanya dalam menentukan kandidat anggota parlemen dan dalam memilih pemimpin. Yang perlu diperbatikan adalah tampaknya PKS menerapkan pola rekrutmen dan ekspansi anggota partai yang unik, yaitu dengan mendorong kader-kader PKS untuk mememiliki banyak anak.]

Keywords: islamic party, political party, parliamentary, PKS

\section{A. Introduction}

This paper discusses the views of the Partai Keadilan Sejahtera (PKS, Justice and Prosperous Party) on democracy and the experience of the party in the recruitment process of members and leaders of PKS to show how the party has implemented the concept of shura as the important value of democracy.

Some scholars believe that Islam is incompatible with democracy. Huntington for example argues that since democracy is a Western construction, it will only develop in societies that share Western values. ${ }^{1}$ Meanwhile Sen argues that the absence of democracy in Muslim societies is due to the way these cultures are portrayed as less tolerant to individual freedom. Ehteshami also believes that Muslim societies and Muslim countries have failed to adapt to modern values such as democracy. ${ }^{2}$

Following upon the above debate as to whether Islam is compatible with democracy or not, in this paper I examine the PKS and attempt to assess the impact of this Islamic political party on the process of democratisation in Indonesia. This study examines the power play of Muslim political party to suggest whether under a democratic system Islam as an ideology needs necessarily be a barrier to multi-party politics,

${ }^{1}$ Samuel P. Huntington, "The Clash of Civilizations?," Foreign Affairs 72 (1993), pp. $40-41$.

2 Anoushiravan Ehteshami, "Islam, Muslim Polities and Democracy," Democratization 11, no. 4 (August 2004), p. 91. 
or not.

Since rank-and-file membership as well as leadership are very significant factors in the existence of a party, it is necessary to know comprehensively about why individuals join PKS what they do once party members. Are they given equal opportunities in selecting their leaders, and how do they do so? It is also necessary to look at whether there are restrictions for members to be nominated as leadership candidates of the parties. Is the process of candidates' selection inclusive or exclusive? How is a candidate nominated? And to what extent is there a degree of institutionalisation in the selection process? By answering these questions, we can determine the extent to which an Islamic political party like PKS practices democratic principles.

\section{B. PKS Views on Democracy}

Two leading figures of PKS who actively advocate that their party support democracy are Hidayat Nur Wahid (the former Chairman of Majelis Permusyawaratan Rakyat/MPR or People Consultatvive Assembly) and Zulkieflimansyah, a member of Indonesian Parliament. According to Zulkieflimansyah, his party is commonly suspected of having a hidden agenda to form an Islamic state in Indonesia once PKS becomes a ruling party. In response to this unfounded suspicion, he insisted that his party believes in modernity in the Indonesian educational system, believes in democracy in the political system and in going back to Islam as a moral code. For him, PKS as an Islamic party should actively involve itself in preventing the country from breaking apart and degenerating into chaos; thus a democratic and economically viable Indonesia must be the final outcome. ${ }^{3}$ To strengthen his argument that PKS accepts democracy and that it should adapt its ideological framework to the reality of democratic politics in Indonesia, Zulkieflimansyah says:

The PKS is not confronted with an authoritarian regime that it must fight against. Instead, it is faced with access to government via a democratic process, and this has translated into the practical realities of bargaining as part of a governing coalition. In other words, the party has to deal with the necessary compromises with other actors within the political system,

${ }^{3}$ Zulkieflimansyah, "Prospects for the Justice and Prosperity Party (PKS) and Political Islam," USINDO Open Forum (Washington DC, June 8, 2006), p. 1. 
including other political parties and the government. ${ }^{4}$

Zulkieflimansyah's view is also supported by another PKS leading figure Hidayat Nur Wahid who believes that democracy is a good political tool to achieve the PKS's political goal. When Wahid was questioned about whether democracy or theocracy is better for Indonesia, he said:

Democracy or theocracy is a product of society's interest. In the Indonesian context, democracy becomes a good tool as long as it is implemented according to democratic means and not manipulative methods. $^{5}$

Wahid even believes that the issue of the relationship between Islam and democracy in the Indonesian context will always appear in the future just as it has been discussed since Indonesian independence in 1945. While many Indonesian people believe that Islam and democracy are in basic conflict, Wahid and his party PKS believe that democracy goes to the roots of Islam in at least three aspects. First, Islam views humankind as equal and universal in spirit. Humans were created as men and women, not with original sin nor as members of a favourite nation of God. The second aspect is the principle of learning. The Quran encourages Muslims to learn and to acquire knowledge from whatever source, regardless of race, ethnicity or nationality. The third aspect is the moral system of Islam that encourages wisdom and not egoism. Wahid further elaborates that the above three Islamic aspects that are relevant to democracy have led to three other consequences. He says:

The first consequence is egalitarianism and tolerance. A second consequence is the democratic principle of shura in Islam. Finally, a third consequence is that of moderation. According to Islam, humans are neither angels nor devils. They should not be materialistic or ascetic. Neither should they be on the far ends of individualism and collectivism. Islam rejects all extremes, whether in the form of consumerism or terrorism. At the same time, Islam encourages a democracy that can protect the weak and poor as well as supporting economic growth. ${ }^{6}$

${ }^{4}$ Zulkieflimansyah, "Overcoming the Fear: PKS and Democratization," The Jakarta Post, December 13, 2005.

${ }^{5}$ See Majalah Tempo, English Edition, 42/VI/June 20-26, 2006.

${ }^{6}$ Hidayat Nur Wahid, "Islam, Democracy and Politics in Indonesia," The Jakarta Post, September 9, 2005. 
Based on his view of the relationship between Islam and democracy, Wahid said that his party was committed to the Medina Charter written by the prophet Muhammad for the multi-religious city state, instead of the Jakarta Charter. This Medina Charter refers to concepts in the Quran such as equality, rule of law, justice and Islamic social services. However, according to Collins and Fauzi, when the issue of the Jakarta Charter was raised again in the legislature in 2000, PKS abstained from voting on whether to accept or reject the motion toadd it to an amended Indonesian constitution. ${ }^{7}$

For Collins and Fauzi, the fact that the PKS abstained from the vote was understandable because although the majority of PKS leading figures agreed that democracy is a good way for PKS to be involved in the political process in the post Soeharto era, there are divisions within the party that derive from the tension between Islamist goals and commitment to democracy. Collins and Fauzi give an example of some PKS leaders like Fachry Hamzah, a current parliament member from PKS, who believes that the party's true political objective is a state based on Islamic law. As quoted by Collins from Djalal, ${ }^{8}$ Hamzah said: "Today democracy is our playing field, but we cannot abandon our religious ambitions." "However, it is necessary to note that Hamzah's statement above was stated by him when he was not a parliament member yet, but still a student activist.

From the above discussion, it is clear that although PKS is suspected of having a hidden agenda to establish an Islamic state in Indonesia, yet up to the present day they still uphold the values of democracy and believe that democracy is the only tool for PKS to be involved within Indonesian politics. Their commitment to democracy also could be seen from the fact that since its establishment, they have participated in Indonesian elections.

${ }^{7}$ Elizabeth Fuller Collins and Ihsan Ali Fauzi, "Islam and Democracy!: The Successful New Party PKS is a Moderate Alternative to Radical Islamism," Inside Indonesia, (Jan-March 2005).

${ }^{8}$ Dini Djalal, "Indonesia's Powerful Student Movement Divided," Far Eastern Economic Review (March 22, 2001).

${ }^{9}$ See Elizabeth Fuller Collins, "Partai Keadilan Sejahtera (PKS): Justice and Welfare Party or Prosperous Justice Party," at http://www.ohiou.edu/pols/faculty/ malley/collins3.html (accessed January 24, 2008). 


\section{PKS: Cadre Party?}

PKS declares itself as a da $w a^{10}$ and party of cadres. In an official document of the party, the first PKS President, Nur Mahmudi Ismail states:

PKS was established not only for da'wa mission but also proposed to be a vehicle for political education for Muslim and other Indonesians. Well organised, a disciplined and strict cadre training and sympathetic approaches to the community are main characteristics of the party. ${ }^{11}$

Contradicted to that of Fealy, Ismail's statement above shows that PKS is not only a party of cadres. ${ }^{12}$ Anis Matta, the current Secretary General of PKS comments on the characteristics of his party saying that: "PKS adalah gabungan antara apa yang kita sebut dengan Nukbbawiyah Jamabiriyah, gerakan elit dan massa" (PKS is a combination of what we call an elite and a mass movement)." ${ }^{\prime 13}$ This means that PKS is a combination of a cadre and mass party at the same time. PKS believes that in the process of the resurgence of the Islamic community, Muslims need a qualified, collective leadership. In this context, an Islamic party in Indonesia, like PKS, can play a role to train cadres to become qualified leaders trusted by the community to lead the country in the future. Matta says:

PKS holds a principle that a leader will perform well if he is supported by a strong mass base. If the relationship between elites and mass supporters is strong, it is hard for a political conspiracy to break cohesiveness between elites and their supporters because during the process of governing the state various challenges may occur. ${ }^{14}$

As the party prepares qualified cadres to become leaders in the future, PKS's members must know the ideology of the party and cannot

${ }^{10}$ Da'wa or Islamic preaching literally means invites people. This is mainly intended to deliver Islamic teachings like Quranic interpretations, Hadith (Prophet Muhammad's speech and acts) and Islamic laws to the people.

${ }^{11}$ Sekretariat Jenderal DPP PKS Bidang Arsip dan Sejarah, Sikap Kami: Kumpulan Sikap Dakwah Politik PK dan PKS Periode 1998-2005 (Bandung: Harakatuna Publishing, 2007), p. 122.

${ }^{12}$ See Fealy's argument in his preface of book written by Yon Machmudi, Partai Keadilan Sejabtera: Wajah Baru Islam Politik Indonesia (Bandung: Harakatuna, 2005), p. vi.

${ }^{13}$ Aay Muhamad Furkon, Partai Keadilan Sejabtera: Ideologi dan Praksis Politik Kaum Muda Muslim Indonesia Kontemporer (Jakarta: Teraju, 2004), p. 206.

${ }^{14}$ Ibid. 
buy their way through a patronage network. PKS also has its own special cadre recruitment, training and selection process. The liqo (Ar: liqa , weekly ideological gathering) training has resulted in a loyal and committed membership. The typology of party as $d a^{\prime} w a$ and a cadre-based party is also confirmed by the former president of PKS, Hidayat Nur Wahid. Wahid also insists that although PKS is a cadre party, it is a non-sectarian and open party, which allows all Indonesian people, whatever his/her religious beliefs, to be eligible to become party members. He further says:

I should add one point. When I talk about the Indonesian people, I do not think only about Muslims. PK(S) is an open party. I have been on panels with various kinds of people: Catholic philosophers such as Franz Magnis-Suseno, Romo Mudji Sutrisno, and Muslim scholars like Cak Nur [late Nurcholish Madjid] and Hasyim Muzadi [Chairman of Nahdlatul Ulama] and others. Many Christian fellows have told me that they like $\mathrm{PK}(\mathrm{S})$. Some have even asked if they, as non-Muslims, can join $\mathrm{PK}(\mathrm{S})$. I've replied that $\mathrm{PK}(\mathrm{S})$ has never required its members to be Muslims. All it requires is that they are Indonesians and that they are over 17 years old. So, if Christians are interested they can join us. But they should realise that we are a cadre-based party, in which we have cadre programmes for our members. We will give them training. ${ }^{15}$

Wahid's argument that his party is open and non-sectarian could also be seen from the party's official platform. In its official statute, Anggaran Rumah Tangga Partai Keadilan (before transforming itself to PKS) chapter 2 , article 8 about its membership, it explains seven requirements to become PKS members. None of these requirements restrict its membership to Muslims only, nor is it restricted to males or certain ethnic groups. The requirements to be a party member are stated to be: (1) Indonesian citizens: male or female, (2) over 17 years old or married, (3) of good behavior, (4) in agreement with the party's objectives, (5), officially apply to became a party member to its headquarter office through Dewan Pimpinan Daerah (District Officers), (6) practicing and concern with membership obligations and (7) who declare to be loyal to the party's principles and platforms. ${ }^{16}$ After PK was transformed into PKS, the

${ }^{15}$ Hidayat Nur Wahid, "Power Means Serving Others," Van Zorge Report (March 18, 2002), p. 7.

${ }^{16}$ DPP Partai Keadilan Sejahtera, Sekilas Partai Keadilan Sejabtera (Jakarta: 1998), p. 64. 
party's statute, Anggaran Dasar, Chapter 3, article 7, on membership also says "all Indonesian citizens who have fulfilled requirements and agreed with the party platform are eligible to become members of PKS."

Non-Muslim members and supporters are also well accommodated by PKS. This argument could be seen from the significant numbers of supporters who voted for PKS during the 2004 general election. According to a voter survey during the 2004 election period made by an Indonesian NGO, Lembaga Penelitian, Pendidikan dan Penerangan Ekonomi dan Sosial/LP3ES, ${ }^{17}$ PKS supporters then were mostly young, middle-income, educated Muslims. Nearly 99 per cent of the PKS voters were Muslim, though the one percent of Hindu and Christian voters was a notable achievement for a party once so defined by its Islamist goals. With regards to a minority group, it is important to note here a statement from the former PKS President, Tifatul Sembiring when he was asked his opinion on minority groups:

If once PKS was given an opportunity to rule the country, PKS would shelter and protect all ethnic groups, not only Muslim. Because the prophet Muhammad has always said that whoever offends a person of a different faith will become my enemy in the hereafter. All citizens will have equal rights. It is even not a problem for PKS to have a non-Muslim president if he/she was elected democratically by Indonesian people. Since most of Indonesian people are Muslim, and through a direct presidential election, it is more likely that Muslim would be elected as president. ${ }^{18}$

Another surprising finding of the LP3ES survey above was that nearly 20 percent of voters categorised their occupation as "housewife," a larger proportion than student voters. Evidently, the PKS platform for a clean and caring government, combined with the party's large percentage of female politicians, hit home with women voters. From these findings one could also argue that women's political interests are well accommodated by PKS. My direct observation as a participant in

${ }^{17}$ Lembaga Penelitian, Pendidikan dan Penerangan Ekonomi dan Sosial (LP3ES) or Institute for Social and Economic Research, Education \& Information is a NonGovernment Organization (NGO), which is non-profit and autonomous. It was founded by a group of intellectuals and student activists on August 19, 1971. Its formation was sparked by the felt need for developing alternative thinking for national development. For more detail of this organization, see www.lp3es.or.id (accessed October 9, 2007).

${ }^{18}$ See Jawa Pos, July 26, 2005. 
the protest rally on Palestine's issue held by PKS convinced me of the survey findings. It can be seen from the fact that more than half of the protestors were females who even brought their children. These mothers said that their children are the next generation of political activists.

The LP3ES survey above also showed that nearly 50 per cent of PKS voters were between the ages of 23 and 35, and the majority had a significantly higher level of education than the average supporter of other Indonesian parties. On one occasion, Tifatul Sembiring (a former PKS President) stated that more than eighty percent of PKS cadres hold university degrees. Yet, what was missing from Sembiring's statement was the fact that, based on my interviews with the members of PKS in the district levels like Depok, Bogor and Kuningan, I found that almost one hundred percent of the party's 'generators' were university students who actively build their network with students from the Senior High Schools in Indonesia. This party's core groups with their own style also influenced their parents and other family members to become PKS supporters in the election.

The PKS believes that its future political success stems from today's younger generation. The quality of the cadres and their integration into the party are very important for PKS development. Thus, the selection of individuals is based on two main criteria: the ability to adapt to a concept of 'life-long education' and continual personal development; and on the ability to maintain a spiritual and truly Islamic dimension in political activism. An important part of the process of life-long education is the ability to accept constructive criticism and feedback from others as a way towards personal improvement. This means that in the PKS, every member is given equal opportunity to become the best members of the party and at the end they will be chosen as top candidates from the party for either national or local parliamentary elections. Because of the process of life-long education and training of the cadres in internal organisation, PKS could be seen as a party that initiated the transmission of democratic values into its constituents.

In the process of cadre training and recruitment, the PKS plays its role as a political party that educates its members on how the political and democratic rules should be followed to achieve their goals. In this matter, it could be argued that PKS functions as an agent of transmission 
of democracy's values to the Indonesian people, or at least to their cadres and constituents. The PKS believes that integrated and well educated cadres, who understand the party platform and the nature of political rules in Indonesia, might help to influence the Indonesian people in general to follow democratic rule. For PKS, to build an Indonesia that is a prosperous, developed and democratic country, it is necessary to start with the smallest unit of community, which is the person as an individual. A good individual will establish a good family. A good family will produce a good community and finally will create a good nation. Thus it could be argued that for PKS, the smallest unit of a nation or state is a person as an individual not villages-communities as was commonly perceived by philosophers such as Aristotle and the Qur'an (13: 11). The official document of PKS says:

To have a qualified cadre, it is necessary to have a special and step by step training. Step by step training started with creating a strong individual because it will produce a good family. Good family will lead to create a good community. Good family and community will produce a good life environment. Because to establish a good state require good individuals and society that can be trusted to take responsibility to govern, creating a good and strong individual is necessary. ${ }^{19}$

The success of PKS in recruiting and training its cadre could be seen from the increasing number of its loyal cadres from only 33,000 in 1999 to 500,000 controllable cadres in 2004. Tifatul Sembiring (current president of PKS) says that his party's target is to have 2.5 million loyal cadres prior to the general election in $2009 .{ }^{20}$ However, if we look at performance of the PKS in the 2009 election, it seems that the party failed to achieve its target. The support for PKS in the 2009 election was a disappointment for the party. PKS has failed to its their ambition to gain at least 20 per cent of the vote. PKS's votes only slightly increased from 7.4 per cent in 2004 to 7.9 per cent in 2009.

\section{Models of Cadre Recruitment}

To achieve its target of 2.5 million cadres in 2009, a number of initiatives have been taken by PKS leaders, ranging from intensifying

${ }^{19}$ DPP Partai Keadilan, Sekilas Partai Keadilan, p. 12.

${ }^{20}$ See Media Indonesia, July 26, 2005. 
cadre training and recruitment, issuing 'letters of instructions', publishing a book entitled Profil Kader Partai Keadilan Sejabtera, 2009 (The Profile of PKS Cadres, 2009), and broadening their international network through PKS members who are studying overseas. I easily discovered the solid Indonesian international students' network of PKS members when I interviewed several PKS cadres during my field research in Kuala Lumpur.

However, the history of PKS's establishment cannot be separated from early da'wa and tarbiyah movements in Indonesia back in the 1980s and 1990s. The da'wa movement in its early stage was only popular among university students and was known as the tarbiyah movement. However, it quickly spread among middle-class Indonesians, particularly after the alumni of tarbiyah groups in leading universities got their permanent jobs. They kept up their tarbiyah activities and recruitment in the places where they worked. One of the characteristics of this movement was the creation of a small discussion group ( halqa, Ar: haläqab) consisting of five to twelve members, to study Islamic teaching intensively. ${ }^{21}$ This kind of group was very popular not only in Islamic universities or Islamic institutions like Institute Agama Islam Negeri/IAIN (State Institute for Islamic Studies), but also in leading secular universities in Indonsia such as Universitas Indonesia/UI, Sekolah Tinggi Akuntansi Negara/STAN Jakarta, Universitas Gadjah Mada/UGM-Yogyakarta, Institut Teknologi Bandung/ITB-Bandung, Institut Pertanian Bogor/IPB-Bogor), Institut Keguruan dan Ilmu Pendidikan/IKIP (now Universitas Negeri Jakarta/ UNJ), Universitas Trisakti Jakarta and other universities in Indonesia. The halqa has succeeded in attracting university students to join the group. Students mostly with a non-Islamic studies background seem to find spiritual guidance in the halqa. Their transitional personality from teenagers to becoming adults seems to encourage them to join this type of group. The halqa groups approach university students, both male and female alike, persuasively and politely and this enables the groups to have a big following and become a mainstream movement in the universities mentioned above.

When the tarbiyah movement was transformed into the Islamic

${ }^{21}$ Aay Muhamad Furkon, Partai Keadilan Sejabtera, pp. 220-231 and see also Ali Said Damanik, Fenomena Partai Keadilan: Transformasi 20 Tabun Gerakan Tarbiyab di Indonesia (Jakarta: Teraju, 2002), pp. 122-138. 
party called PKS, both university students and alumni actively involved in the tarbiyah movement became active members of the party and continued to use the halqa style in recruiting and maintaining their members. They even further created what it called Multi Level Dakwah/MLD, which seems to be similar to the Multi Level Marketing / MLM) approach in business. The principle of this MLD was that each member should intensively approach their families or friends to participate firstly in halqa activities and in the end attract them to join the party. This approach is also known as the cell theory of recruitment.

Strategies have been applied by PKS not only to spread out and recruit new members but also to maintain and develop their members' loyalty to the party by making regular cadre training such as liqo and muqoyyam (Ar: muqayyam) as part of halqa and tarbiyah movements. Further, PKS has implemented two pillars of their tarbiyah movement, which are straight manhaj $j^{22}$ and qualified murabbi (taken from Arabic literally means a da wa speaker. It then refers to a leader in a halqa who guides their members in Islamic teachings). While a leader of ḩalqa is called murabby, the members themselves are called mutarabby (guided students). Liqo and muqoyyam have been selected as good training methods to create solid and qualified cadres of PKS.

\section{Liqo or Ta'lim}

Liqo literally means 'meeting'. This term is taken from the Arabic and used by PKS members to refer to weekly gatherings consisting of small groups (5-12 persons) to learn Islamic studies under the guidance of more senior and qualified Islamic teachers of PKS members called murabbi. Although generally they discuss Islamic teachings in this gathering, it is also used as a tool to strengthen cadre relationships among the party members.

The liqo weekly gathering is usually held in one of the houses of the members, or if it is held in campuses or schools, in mosques or mushola (a small place provided for Muslims to pray) located on the campuses. It is then very common to find small gatherings of students

${ }^{22}$ Manhaj is taken from Arabic word literally meaning systematic steps to be followed to achieve an objective. Straight manhaj here refers to steps or programs that have been done and exemplified by the prophet Muhammad in his da'wa. 
at Arief Rahman Hakim mosque in Depok, University of Indonesia or at Salman Mosque in Bandung Institute of Technology. Their gatherings are easily recognised because the members sit in a semi-circle with a murabbi positioned in front of them.

Based on my interviews with the liqo groups, direct observation and active involvment in several liqo activities during my fieldwork in Jakarta, I found that the liqo gathering seems to be an effective method of cadre recruitment for PKS because this activity can make the members more integrated and loyal to the party. Interpersonal relationships among the members can be effectively maintained by the party because of the frequent meetings among the members. With their systematic method of gathering, each member who has attended liqo for quite a long period and is considered to be capable enough to transform knowledge gained during the liqo, is urged to create another new liqo group and try to recruit new members. This liqo method is clearly influenced by the method used by the al-Ikhwan al-Muslimun movement in Egypt to recruit their members. While PKS uses the term liqo for this method, al-Ikhwan alMuslimun calls their method an usrah. ${ }^{23}$ Damanik argues that liqo and usrab have similarities in style, objectives and principles when performing the liqo gathering. There are three principles of liqo or usrah activities that should be fulfilled by the members, namely, ta'aruf (knowing each other), tafabum (understanding each other), and takaful (responsible to each other). Through these principles, interpersonal relationships among the members are established..$^{24}$ Damanik is correct that between them, liqo and usrah have similarities not only in term of their small number of groups but also in terms of the curriculum they teach. During my direct observation while involved in liqo activities, I found that there are not more than ten members in each group and among the liqo members; the interpersonal relationships are very strong. When I was firstly introduced to attend the liqo group meeting in Mampang Prapatan, South Jakarta,

${ }^{23}$ Literally meaning family in Arabic, the term usrah, used to describe a type of Islamic education group can be tracked back to al-Ikhwan al-Muslimun movement in Egypt. According to Hasan al-Bana, the founder of this movement, usrab is a family which binds Muslim into brotherhood on the basis of Islam. For more explanation see Rifki Rosyad, A Quest for True Islam: A Study of Islamic Resurgence Movement Among the Youth in Bandung, Indonesia (Canberra: Australian University Press, 2006), 51-55.

${ }^{24}$ Ali Said Damanik, Fenomena Partai Keadilan, p. 128. 
the murabby explained the objective and principles of liqo gatherings as the same as mentioned by Damanik above. Fortunately, I was able to easily join in the liqo gathering because I stayed in a shared rental house in Mampang (PKS headquarters was also located in this place) in which all the members are also liqo groups' activists and they approached me in person and asked about my religious and educational backgrounds before I could join their liqo activities.

The leader of the liqo that I attended explained the principles of liqo stating that each member should be aware about: ta'aruf, tafabum and takaful. ${ }^{25}$ Ta'aruf is the first principle of liqo activities. Each member involved in the same liqo group should know each other well so as to develop interpersonal ties with the others. My experience in being involved in such a gathering showed me, for example, the importance of pretending to be a close relative of a liqo member in order to be easily accepted as a group member. Liqo members should establish close relationships in the sense of ukhuwah (brotherhood), by knowing the name, address and status of others in their family. Even among the members, each should know each other's psychological state, way of thinking, self-capability, and economic condition. After the principle of ta'aruf is embedded in the psyche of the members, the second principle, which is tafahum, should be upheld by them. This principle of tafahum or "understanding" consists of three factors that can strengthen relationships among the members. They are, (1) strengthening love and compassion for each other, (2) negating hatred that can break relationships and, (3) avoiding dispute among the members. And the last principle which is considered to be the result of the process of ta'arufand tafahum, is that of takaful (responsibility to each other). This principle implies that every member looks after the others, particularly when one of the members faces difficulties.

To extend halqa or liqo membership, which implies creating more numbers of PKS cadres and members, each liqo member has to undertake two types of compulsory recruitment: fardi and jama'i. Fardi recruitment means that a member of PKS initiates himself or is recommended by murabbi to recruit one or two persons to become a member of his liqo or halqa group. Several steps should be followed by a member to recruit new members, which are: 1) Each ḥalqa member firstly should

${ }^{25}$ Ibid. 
find a candidate to be recruited; 2) the candidate is introduced to other members and given information on what is taught and done in balqa;3) the candidate is observed confidentially whether he is capable enough to become a member; 4) the result of the observation is discussed among halqa members; and 5) a candidate is approved to become a halqa member. ${ }^{26}$ From this process of recruitment one could argue that there are enough bases for determining that a cadre or member of PKS is now fully integrated and loyal to the party.

Jamai'i recruitment is a collective recruitment of tarbiyah or halqa members and at the same time recruitment of PKS members through formal and informal activities. Several activities are considered to be part of jama'i recruitments, as follows: 1) recruitment through party activities, 2) recruitment through Lembaga Dakwah Sekolah/LDS (School Da'wa Institution) or Lembaga Dakwah Kampus/LDK (University Da'wa Institution), and 3) recruitment through other institutions such as Majlis Ta'lim (Islamic learning gatherings), Ramadhan activities and Bakti Sosial (community social-services). The recruitment through party activities is the recruitment of a tarbiyah member arranged officially by a member of the party through both Training Orientasi Partai Satu (The First Party Orientation Training) and Training Orientasi Partai Dua (The Second Party Orientation Training).

PKS also recruits their tarbiyab members through active involvement in da'wa institutions available both in schools (high schools) and universities. This means that PKS members have actively promoted their programs to recruit party members not only among university students but also among students in high schools. At the high school level, PKS members have tried to approach students to actively involve them in da'wa activities in their schools, while in fact cadres of PKS would become their mentor in their activities and indirectly invite them to become halqa and PKS members. PKS programs have thus been introduced to the high schools students, so that when these students enroll later at university, they tend to continue to be actively involved in the da'wa movement at the university level as PKS cadres. At the high school level, PKS members influence students to actively get involved in Rohaniawan Islam/Rohis

${ }^{26}$ DPP Partai Keadilan Sejahtera, Manajemen Tarbiyah Anggota Pemula (Jakarta: Syaamil Cipta Media, 2004), pp. 11-12. 
activities. Rohis is an institution of da'wa in high schools in Indonesia. Almost all high schools in Indonesia, except Christian or Catholic schools, have this kind of institution. Coordinated by the students with the help of teachers of religion subjects, this institution regularly performs Islamic activities such as religious discussion, celebrating Islamic festivals and coordinating Islamic ritual activities like daily prayer and Qurban (slaughtering animals during Idul Adha celebrations).

In the ḩalqa or liqo program, PKS provides special curricula consisting of planning activities and materials that should be taught by murabbi to halqa members. This curriculum was set up by the party, particularly by their division on cadres called Departemen Kaderisasi (Department for Cadre Preparation). For new members of PKS, a halqa guideline is called Manajemen Tarbiyah Anggota Pemula (Tarbiyah Management for Beginner Members). In this guideline, the party set its tarbiyah curriculum as well. The curriculum consists of four general topics; 1) basic teachings of Islamic studies; 2) basic teachings of skills and self-empowerment, 3) da'wa and Islamic thought, and 4) social sciences.

The materials given during the halqa activities include Hadits Arbain (the Forty Hadith of the Prophet), Marifah Diinil Islam (Understanding of Islamic Religion), Pokok-pokok Ajaran Islam (Main Tenets of Islamic Teachings), Marifatullah (Understanding of God), Taubidullah (Oneness of God), Taubidul Asma' was Shifat (Oneness of Name and Characteristics of God), Ma'na Syahadatain (The Meaning of Two Declarations [being Muslims/syabadat]), Syarat-syarat Diterimanya Syahadat (Requirements of syahadat Acceptances), Beberapa Hal yang Membatalkan Syahadat (Factors that Abrogate Syahadat), Arti Laa ilaaba illallah (Meaning of There is no God but Allah), Siksa Kubur (A Grave Punihsment), Ibsan (Gracious), Menjadikan Syaiton sebagai Musub (Make an Evil as an Enemy), Kebutuban Manusia terbadap Rasul (the Need of community to the Prophet), Ta'rif ar-Rasul (Meaning of Messenger), Makanatur Rasul (the Position of Messenger in Religion), Shifatur Rasul (Characteristics of Messenger), Wazhifatur Rasul (the Duty of Messengers), Khasaishu Risalah Mubammad (the Specifications of Muhammad Teachings), Wajibatul Muslim Nahwa Rasul (Muslim Obligations to the Messengers), Nataiju Risalab Mubammad (the Excellence of Muhammad's Messages), Aurat dan Pakaian (Aurat [private parts of body in Islam] and the Clothes), Akblak kepada Sesama 
Muslim (Ethics to Another Muslims), Memenubi Janji (Fulfilling Promise), Menundukkan Pandangan (Keep the Eyes from Sins), Tidak Berteman dengan Orang Buruk (Avoid be Friend with Wrong Doers), Menjaga Kehalalan Harta (Keep the Property Halal/Lawful), Birrul Walidain (Being Good to the Parents), Ghirah pada Keluarga (Protect Family), Memilib Pasangan (Choose the Partners), Ta'rif Al-Quran (Meaning of the Quran), Hidup Bersih dan Sehat (Live Clean and Healthy), Makan dan Minum (Eat and drink), Ghirah Agama (Protect the Religion), Abamiyatut Tarbiyah (the Importance of Education), Marbalah Makiyah dan Karakteristiknya (to Know Mecca and its Life Characteristics), Abwalul Muslimin (Behave as a Muslim), Perjalanan Gerakan Dakwah Pemuda (the Da'wa of the Youth), Dakwah di Negeri-Negeri Muslim (Da'wa in Muslim countries), Ghazwul Fikeri (the War of thoughts), Zionis Internasional (International Zionism), Gerakan terselubung yang Memusubi Islam (Hidden Movements to attack Islam), Lembaga-lembaga yang Menentang Islam (Organisations that oppose Islam), Berpartisipasi dalam Kerja-kerja Jama'i (Participate in the Community Activities), Sistim Politik dan Hubungan Internasional (Political Systems and International Relations), Ilmu Allab Taala (the Knowledge of God), Saluran Politik (Channels of Political Aspiration). ${ }^{27}$

From the mentioned-materials of halqa, it is clear that almost all materials taught in the tarbiyah or halaqah activities are based on Islamic teachings. This means that although PKS claims that its membership is open to all Indonesian people whatever their religious beliefs are, it is most likely impossible for non-Muslim members to be involved in balqa activities. However, it could be assumed that for the non-Muslim members, they might participate and be involved in other party activities, which are not related directly to Islamic or da'wa activities, such as social activities.

\section{Muqoyyam Activities}

Muqoyyam literally means to inhabit or camp. This term is used by PKS to refer to cadre training activities in which the cadres are trained for about three to five days living in an open space (field), jungle or mountains. In this training, the cadres are not only trained in physical activities like mountain climbing but are also taught Islamic studies and related activities

${ }^{27}$ Ibid, pp. 23-24. 
like performing midnight prayer and Quranic reading collectively to strengthen their communal relationship. The book of guidelines for PKS cadre training defines muqoyyam as "Sarana tarbiyah jasadiyah melalui latiban fisik dan simulasi ketaatan agar peserta siap menjadi prajurit dakwah dan siap menerapkan nilai Islam di tengah masyarakat' (a medium of personal da'wa through a physical training and a loyalty simulation to make a member ready to be a da'wa soldier and ready to implement Islamic teachings in the centre of the community). ${ }^{28}$

From the above definition, it is clear that moqoyyam is not only focused on physical activities but also on spiritual teachings to create a PKS cadre who is loyal and ready to become a da'wa activist. The objectives of muqoyyam, as written in the book of guidelines of the party, are to, 1) make PKS cadres accustomed to live in an open space with very simple facilities; 2 ) to create a mentality among PKS cadres of loyalty to their leader; 3) to improve the discipline of the cadres and firm adherence to the party's rules; 4) to make PKS cadres accustomed to living under comprehensive Islamic guidance; and 5) to train PKS member to be aware of living healthily and being aware of their surroundings. ${ }^{29}$ To achieve these goals, activities during muqoyyam have been set up by PKS. They are divided as such: forty percent of programs comprising of physical activities to improve cadre's endurances; twenty five percent of programs to improve members' loyalty; twenty percent to improve the spiritual capability of the members, which in the end motivates them to be ready as da'wa and party activist; ten percent to improve their awareness of Islamic civilisations; and five percent as entertainment for the members.

This moqoyyam activity is coordinated and held at every level of the PKS organisation from the Dewan Pengurus Ranting/DPRa (office of the party at the village level) to Dewan Pengurus Pusat/DPP (office of the party at the national level). DPRa is the lowest level of the official structure of PKS at the kelurahan/desa (village) level, while DPP is the highest at the national level. The cadres of PKS at every level should participate in this muqoyyam activity at least once a year. ${ }^{30}$

Besides these two main programs (liqo and muqoyyam), to strengthen

${ }^{28}$ Ibid, p. 42.

${ }^{29}$ Ibid, p. 43.

${ }^{30}$ Interview with Umung Anwar Sanusi (a parliament member from PKS) in, Jakarta, April 21, 2006. 
the communal relationships among the cadres, PKS also has several other irregular programs such as daurah, mabit, and riblah. ${ }^{31}$ These programs for cadre training are very unique if compared to other parties, even other Islamic parties in Indonesia like the Partai Persatuan Pembanguan/ PPP (The United Development Party) and Partai Bulan Bintang/PBB (The Crescent Star Party), which lack such cadre training activities. This uniqueness can be attributed to the fact that the establishment of PKS was originally initiated by da'wa or tarbiyah activists who were very active in the universities in Indonesia, as explained previously.

\section{Student Networking Overseas}

To maintain the integrity of the members who are living or studying overseas and to expand its cadre membership, PKS also maintains an international network. It is very common to see how PKS cadres, who are studying overseas, keep up their ḥalqa or tarbiyah activities. Different from other parties in Indonesia, PKS has an overseas branchcalled Pusat Informasi dan Pelayanan PKS/PIP-PKS (The Information and Service Centre of PKS). The PIP-PKS is not only involved in maintaining their cadres' mutual relations by performing liqo and other such activities, but is also active in disseminating PKS programs and ideas to Indonesians-students and workers alike--living overseas. The PIP-PKS can be found in Australia and New Zealand, Japan, Malaysia, Singapore, Egypt, United Kingdom and South America. ${ }^{32}$

The PIP-PKS is part of the centralised network of the party that keeps the members interacting with each other and promotes PKS ideas, activities and programs to Indonesian people overseas. The organisation has not only held party activities prior to election campaign but has also routinely held weekly liqo meetings among the members. This overseas network of PKS has also set up websites, which are well maintained and regularly updated. For example, the PIP-PKS website for Australia and New Zealand (http:/ / www.pks-anz.org) consists of several main menus

${ }^{31}$ Mabit literally means sleepover. This activity refers to a night spiritual gathering (usually held once a month) attended by a liqo group and his murabbi. For a detailed explanation, see Ali Said Damanik, Fenomena Partai Keadilan, pp. 129-133.

32 Based on my observation in Kuala Lumpur during my fieldwork and in Singapore, these international networks are solid and have several activities to promote PKS's programs and to attract overseas Indonesian voters. 
such as Berita Kita (Our News), Artikel Tarbiyah (Articles on Tarbiyah), MP3 Ceramah (MP3 on Religious Speeches), Bayan dan Fatwa Dewan Syariah (Explanation and Fatwa of Dewan Syariah [Shari' ab Council]), Kisah Anggota Legislative (Story of Parliament Members), Radio Chat and Forum Diskusi (Discussion Forum). Berita Kita (Our News) contains information related to PKS events and activities of PKS leaders in Indonesia. For example, under the subheading Tifatul: Akbiri Bencana dengan Mubasabah dan Bertaubat (stop a disaster by introspection and repentance), it covered PKS President Tifatul Sembiring when he delivered a speech to welcome Islamic New Year 1 Muharram 1429 (10 January 2008) at Pondok Indah mosque in Jakarta. It also reported how the head of MPR from PKS, Hidayat Nur Wahid, advised PKS cadres and members not to be influenced and provoked by negative news of PKS in the media when he attended a meeting of PKS cadres in South Jakarta on 6 January 2008. This news can be found under the subheading Hidayat Nur Wabid: Dampak Fitnah, PKS Bisa Ditinggalkan (Hidayat Nur Wahid: the impact of calumny, PKS could be left behind). Other news related to current PKS activities is regularly posted under this heading. From this, one could argue that the PIP-PKS Australia and New Zealand have been actively involved in disseminating information related to PKS not only for their members but also for the public who visit this website.

The second and third main headings of the website are called Artikel Tarbiyah (papers related to Tarbiyah teaching) and MP3 Ceramah. These headings are collections of both Islamic articles and MP3 files written by Muslim scholars mainly from PKS. These headings seem to propose to enrich PKS members' knowledge of Islamic teachings. Examples of articles and MP3 files on these headings are Sekali Shaum Tetap Shaum (Once fasting, you should fast forever), Masalah Khilafyah (the problem of difference of opinions), Kriteria Ulama dan Ilmunya (The Criteria of Muslim scholars and their competences), Ciri-ciri orang Bertaqwa (the characteristics of a Gods fearing person) and Pendidikan Dini (Early childhood education). ${ }^{33}$ By uploading Islamic articles and MP3 files on Islam in this website, PIP-PKS helps not only PKS members in New Zealand and Australia, where this website was set up, but also readers around the world affiliated with PKS who visit this website, to

${ }^{33}$ See www.pks-anz.org (accessed January 21, 2008). 
understand Islamic teachings, which of course is in line with the PKS's vision and mission.

The forth main heading of the website is called Bayan dan Fatwa Dewan Syariah Pusat PKS (Explanation and Fatwa of Shariah Central Board of PKS). This heading consists of formal PKS responses and explanations on Islamic issues in Indonesia, such as the explanation on when Idul Adba and Idul Fitri should be celebrated; the PKS fatwa on natural disasters and how PKS members should react to it; PKS responses to the insults against the Prophet Muhammad in the Denmark media; and the position of PKS in regard to increasing fuel prices. The information under this heading not only can help PKS members or supporters to understand their party's responses to policies on both Islamic and national issues in Indonesia, but also can inform non-PKS members about the party's position on certain issues which, in the end, might make them support the PKS if they have come to believe that the PKS responses on certain issues represent their interests.

Another heading of this website is Kisah Anggota Legislative Story of Parliamentarians). This heading reports and explains what has been done by parliamentary members from PKS. This is a good example of how the PKS explains, not only to their constituents but also to the public, the performance of parliamentary members from the party. Knowing how parliamentary members actually perform helps the public to judge whether these politicians are capable enough so as to be nominated again in the next election. This PIP-PKS website also provides information on PKS networking by citing website addresses related to PKS, such as the websites of Dewan Pimpinan Pusat (PKS office at National level), Dewan Pimpinan Wilayah (PKS office a provincial level), Dewan Pimpinan Daerah (PKS office at district level) and Dewan Pimpinan Ranting (PKS office at subdistrict level).

PKS cadres intensively use the internet as a medium to promote their party. Looking at the huge number of websites related to PKS one could argue that, compared to other parties in Indonesia, the cadres of PKS are more aware of how to use online media as an effective tool to make their party better known to the public. These internet websites also makes it easier for the cadres of the party to contact each other and coordinate amongst their members. The struggle of PKS cadres to set 
up websites to promote party activities and programs, is not only actively carried out by PIP-PKS Australia and New Zealand but also PIP-PKS institutions in Japan, Malaysia and in other countries.

\section{Big Family}

Based on my interviews with members and cadres of PKS during my visit (attending PKS Musyawarah Daerah or District Annual Meetings) to several PKS offices at district levels in Bekasi, ${ }^{34}$ Bogor,,${ }^{35}$ and Kuningan, ${ }^{36}$ clearly they believe that it is good for Muslims to have many children. They back up their argument by saying that the Prophet Muhammad encourages Muslims to have a lot of children because the Prophet will be proud in the life hereafter to see that his followers are much bigger in number compared to other Prophet's followers. Having a lot of children, then, could be seen as a typical characteristic of PKS cadres. It is commonly known in Indonesia that not only cadres but also PKS members would have more than three or four children in the family. Let us look more closely at their arguments in support of many children. PKS members cite an hadith mentioning "the Prophet Muhammad commanded his followers to marry and forbade them to be unmarried (to be single all life). You should marry and have lot of children because I will be proud to have many followers in front of other Prophets in the hereafter (Narrated by Anas ibn Malik)." ${ }^{37}$

Believing that as Muslims they should obey and follow the Prophet's commandments, members take the literal meaning of the above badith to support their argument. Eighty two per cent (thirty seven out of forty five parliament members from PKS), for instance, have four children or more and only eighteen percent have two children or less. Some

${ }^{34}$ It was held on April 28-30, 2006 in Asrama Haji Bekasi under theme 'Bangun Kebersamaan Sejahterakan Kota Bekasi' (Build a Togetherness and Make Bekasi Prosper).

${ }^{35}$ It was held on May 20-21, 2006 in YPI-Ciawi Bogor under theme 'Bangun Kepedulian Menuju Bogor Sejahtera' (Build Awareness to Make a Prosperous Bogor).

${ }^{36}$ It was held on May 13-14, 2006 in Hotel Ayong Linggarjati Kuningan under theme 'Wujudkan Keadilan Sejahterakan Kuningan” (Realise Justice and Make Kuningan Prosper).

${ }^{37}$ Ibnu Hibban, Shabih Ibnu Hibban: Chapter Marriage, No. 4028. For a detail explanation of this book, see http://www.almeshkat.net/books/open. php?cat $=8 \&$ book=426 (accessed February 10, 2008). 
female parliament members from PKS, Yoyoh Yusroh, for example, has thirteen children, whereas Aan Rohanah has eight children and Nursanita Nasution has seven children. ${ }^{38}$ The general norm in Indonesia for numbers of children is having no more than three children. For PKS members, it is important to have huge numbers of children because they believe that family members could become the main pillar of cadres of the party. Although I cannot find any official documents of the party stating that PKS cadres should have a lot of children to increase the numbers of cadres and members, it is clear from almost all members of PKS I have met and interviewed that they have or are planning to have as many children as they can. In addition, during the rally protests held by PKS on the issue of Palestine in Jakarta that I attended, PKS members would happily takes their children and even babies to the rally.

\section{E. PKS Leadership Recruitment}

After discussing the PKS style of recruiting their members, in the following section, I will examine the way of PKS select their leaders to show how this Islamic party tries to reconcile between democracy and Islamic values at the same time. To do so, my discussion will now be focused on how the PKS selects their leaders (Majlis Shura) and how recruitment processes have been set up to select the party's candidates for parliament members.

\section{Majlis Shura Selection}

Hidayat Nurwahid (the former PKS President) argues that one of the pillars of democracy in Islam is the concept of shura. For him shura is one of the four main principles along with justice, equality, and human dignity, of a political organisation in Islam. Shura is based on three perspectives. One is that all persons in a society are equal in human and civil rights. A second is that the majority view is best in deciding public issues. The third is that justice, equality and human dignity can best be obtained through shura governance. ${ }^{39}$ Thus, it would be reasonable to

${ }^{38}$ Detailed information pertaining to the number of family members of PKS parliament members is available at http://www.indopolitik.com/tokoh/anggota_dpr. php (accessed January 22, 2008) as quoted in Hepi Andi Bastoni and Syaiful Anwar, Penjaga Nurani Dewan (Jakarta: Pustaka Al-Bustan, 2006).

${ }^{39}$ The Jakarta Post, September 9, 2005. 
look at why PKS put Majlis Shura as their highest institution in the party structure.

According to the Anggaran Dasar of PKS chapter 5, article 10, Majlis Shura is the highest institution in the party structure and functions as the consultative body or Ablu-l-Hall wa-l-Aqdi (literally means the people who loose and bind). It consists of at least 35 members, according to the PKS constitution, and has full authority not only to articulate the party's vision and mission, but also to select the president of the party and decide other strategic party decisions. Due to its important position and strategic role in the party structure, one might ask what the process of PKS in selecting its Majlis Shura members is. Does PKS implement democratic rule - that is, giving equal opportunity to its members around Indonesia to select its Majlis Shura members?

The implementation of internal democracy in PKS could be seen from the selection of 50 Majlis Shura members for the period 2005-2010. These Majlis Shura members are directly selected by the Kader Inti (Core cadres) of the PKS around Indonesia. All Kader Inti in a district level have an equal opportunity to choose Majlis Shura members freely and fairly, without restrictions. The question, however, is why is it only Kader Inti that have an opportunity to select Majlis Shura members? Why don't all cadres and constituents of PKS have equal rights to vote for selection of Majlis Shura members?

According to Sapto Waluyo, although not all PKS members and constituents have a voice in choosing Majlis Shura members, the PKS's effort to implement its internal democratisation process in the election of the Majlis Shura should be appreciated when compared to that of other political parties in Indonesia. For Waluyo, it is understandable why the PKS has still limited this selection participation to only Kader Inti. To accommodate all PKS cadres and constituents in Majlis Shura election, PKS would need infrastructure, human resources and, of course, a lot of financial resources. ${ }^{40}$ As a new party with a small funding resource, the PKS effort to hold an internal general election to choose Majlis Shura members could be seen as a starting point to educate their cadres on how democratic rule should be implemented in the party. It is not impossible

${ }^{40}$ Sapto Waluyo, Kebangkitan Politik Dakwah: Konsep dan Praktik Politik Partai Keadilan Sejabtera di Masa Transisi (Bandung: Harakatuna, 2005), p. 180. 
to look to a future in which this internal general election will be attended by all PKS members and constituents. The experience of the PKS to mobilise its cadres in selecting the members of Majlis Shura has surprised political activists from other parties, such as Golongan Karya/Golkar, Partai Demokrasi Indonesia Perjuangan/PDI-P, and Indonesian people in general since PKS is a new party compared to these two big parties. In the history of political development in Indonesia, one would argue that it is very rare to see a political party that could mobilise its cadres and constituents in the way the PKS has done in choosing its Majlis Shura members. Usually, in terms of choosing top leaders of political parties like Golkar and PDIP, only political elites were involved in the process, not cadres and constituents as have been experienced by PKS. ${ }^{41}$

After the selection of 50 Majlis Shura members, these members held another internal democratic election to select the head of Majlis Shura and also to select the president of the party. For the period of 2005-2010, after an intensive musyawarah (deliberation) among Majlis Shura members, they appointed Hilmi Aminudidin as the head of this institution and Tifatul Sembiring as the President of PKS. The decision of the Majlis Shuro to choose Tifatul Sembiring as the president of PKS for 2005-2010, was accepted totally by all party cadres and constituents. This smooth process of 'succession' of party leaders from Hidayat Nurwahid to Tifatul Sembiring could be seen on the one hand, as a sign of the kedewasaan berpolitik (political maturation) of PKS members, and on the other hand as an indication that the process of internal democratisation in the party was running well. As commonly known in Indonesian political developments, the succession of party leaders sometimes could lead to an 'internal conflict in the party' as can be seen from the conflicts within the Partai Kebangkitan Bangsa/PKB, Partai Persatuan Pembangunan/ PPP, and PDI-P.

The process of musyawarah and democracy among Majlis Shura members can also be seen from the PKS decision to support Amien Rais as candidate for president in the 2004 first round presidential elections. In connection with this, Zulkieflimansyah, a parliament member from PKS (2004-2009 and 2009-2014 terms), has this to say:

Internally, the PKS has also begun to learn the art of democratic practice.

${ }^{41}$ Ibid. 
For example, in the run-up to the presidential election in 2004, PKS leaders had to decide on which candidate to support. A segment of the party advocated support for Gen. (ret) Wiranto for pragmatic reasons, chiefly the calculated chance of Wiranto winning the election. The majority, however, supported Amien Rais. In the end Majlis Shura voted in favour of Amien Rais, despite strong pressure for the party to throw its weight behind Wiranto. ${ }^{42}$

\section{Selection of Parliament Candidates from PKS}

The PKS internal general election was not only held to select the head of Majlis Shura and President, but also to nominate the candidates from the party to be chosen as parliamentarians in the 2004 Indonesian general election. Almuzammil Yusuf (parliamentary member for PKS), as quoted by Waluyo, says that internal general elections in PKS were held to respect the cadre's voice in selecting representatives to be parliamentary members. Through the internal election process, PKS hoped that the party's solidarity would be strengthened and public accountability for the parliament's candidates could be realised. ${ }^{43}$ The names of prospective candidates were proposed by all PKS cadres in Indonesia and abroad and the ranking of its list was determined based on the cadres' vote.

This PKS internal general election is very significant for the development of democracy among the party's members. This event is also important because through its parliamentary candidates were directly voted by all members of the party. Here, we can see how the process of internal democracy among PKS members works, which is different from other political parties in Indonesia. It is commonly known in Indonesian politics that the candidates for parliament members, proposed by a political party, are usually decided by the political elites in Jakarta. Thus, whoever usually wants to be nominated as a parliamentary candidate, if he/she comes from the district level, should fulfil very strict requirements, the most important of which is financial.

In PKS, to be nominated for parliament, a candidate should be from the highest ranks amongst the members and be chosen by the party's cadres directly. The criteria for one's candidacy are not based on how

${ }^{42}$ The Jakarta Post, December 13, 2005.

${ }^{43}$ See Sapto Waluyo, Kebangkitan Politik Dakwah, p. 186. 
much money he/she has and how close he/she is to the party's elites, but based on four criteria: Integritas (integrity), kapabilitas (capability), basis massa (mass base) and lobi strategi (lobbying strategy). Integrity spells out as kebersiban ideology dan moral, komitmen terbadap visi dan misi partai tidak tercemar (clean ideology and morality, committed to the mission and vision of the party); capability is mentioned as manajerial, kepemimpinan, dan teknis legislasi, budgeting, legal drafting dan pengawasan publik (managerial, leadership and legislation technique, budgeting, legal drafting, and public accountability); Mass base refers to dukungan konstituen yang konkrit dari daerah asal, dan komunitas yang jadi target kerjanya (Concrete constituents support from the area in which the candidate was originally from), whereas strategic lobbying means mempengarubi media massa dan tokoh penting di masyarakat yang menjadi pembentuk opini dan pemutus kebijakan (Influence mass media and a public figure who has a capability to form public opinion and to decide policy). These mentioned criteria were strictly implemented in choosing the legislative candidates from the PKS not only at the national level but also at the levels of Dewan Perwakilan Rakyat Daerah Tingkat I (Parliament Member at Provincial Level) and Dewan Perwakilan Rakyat Daerah Tingkat II (Parliament Member at District Level). This means that the PKS is really concerned with the democratisation process in its internal structure and gives equal opportunity to its cadres at every level of the party structure to become parliament members for PKS.

The PKS' democratic struggle for the public interest and not for the party's benefit can also be seen from PKS figures who initiated the transfer of leadership once a party leader began to hold an important position as a government officer. For example, when the former president of PKS, Nur Mahmudi Ismail, was chosen as Minister of Forestry and Plantation (Menteri Kehutanan dan Perkebunan) under Abdurrahman Wahid's presidency, he resigned as the president of PKS. He states that his resignation as the President of PKS was to prove his commitment as a government officer to be unaffiliated formally to any group or any party. Thus, he could fully dedicate himself to the interests of the people and the country and can concentrate on his work as a public official. Although his resignation surprised political elites in Indonesia, Nur Mahmudi believed that his resignation as the PKS President would not influence the party's performance because PKS has a unique leadership 
characteristic, which they call a collective leadership. ${ }^{44}$ PKS does not solely rely on the individual leadership figure as other parties demonstrate.

Nur Mahmudi's resignation was finally bequeathed by PKS after the party held a collective meeting between Majlis Shura, Majlis Pertimbangan Partai, Dewan Syariah and Dewan Pimpinan Pusat Partai Keadilan on 16 April 2000. This again shows how democratic decision through musyawarah has been taken by PKS leaders to decide upon such an important matter. After the decision was made by the party, PKS then appointed its vice president, Hidayat Nur Wahid, as acting president of the party until a Musyawarah Nasional (National Party Meeting) in which Nur Wahid was again officially selected to become the president of the party. In his comment on Nur Mahmudi's resignation, Nur Wahid says: "...kita ingin mengingatkan bangsa ini babwa my loyalty to my country not my party kita buktikan... "(We want to remind Indonesians that the slogan of 'my loyalty to my country not to my party' is implemented by PKS)." 45

The example of Nur Mahmudi's resignation, when he became the Minister under Wahid government, was also followed by Hidayat Nur Wahid when he was chosen as the chairperson of MPR. Before being elected the head of the MPR, Nur Wahid was the party president, a post he had held since 2002. He handed over leadership of PKS to Tifatul Sembiring in a gesture he explained as an effort to "prevent the conflict of interest between state and party." ${ }^{46}$ The tradition of transferring leadership among PKS elites breaks with the tradition of previous Indonesian leaders, like former president Megawati Soekarnoputri who maintained party leadership (as a head of PDIP) once in power, or the former president Abdurrahman Wahid who maintained his position as the leader of Dewan Shura of PKB once he became the president. Though leadership of the MPR is said to be more ceremonial than functional, if there was an effort to impeach the current president, Nur Wahid would be one of the politicians with the final say. ${ }^{47}$

${ }^{44}$ Kompas, May 4, 2000.

45 Ali Said Damanik, Fenomena Partai Keadilan, p. 293.

${ }^{46}$ See, The Jakarta Post, October 23, 2004.

${ }^{47}$ Before 2004, and the amendments to the 1945 Constitution, the MPR was the highest governing body in Indonesia. With the President and Vice President thereafter elected directly by the people and with the constitutional amendments, MPR no longer be the highest governing body but stand on equal terms with the Dewan Perwakilan 


\section{F. Concluding Remarks}

In this paper, I have shown that while the compatibility between Islam and democracy has been questioned by scholars like Samuel P. Huntington, Ehteshami and Amartya Sen, who tend to believe that Islam is inimical to democracy, PKS leaders have always believed, and have sought to prove, that Islam and democracy can walk together and that at the very least democratic values can be implemented in Indonesian where Muslims are the majority. Hidayat Nur Wahid, as discussed above, argues that democracy goes to the roots of Islam and the Indonesian context in which it exists; democracy is a good political tool for an Islamic party like PKS to achieve its political goals.

In their response to democracy moreover, it is clear that PKS accepted democratic values, such as refraining from discrimination based on language, nation, and religion as can be seen in the parties' policy on membership discussed above. Their adherence to the democratic process can be seen from the fact that while they claimed to be an Islamic party, they gave equal rights to all Indonesian to join. It did not matter if they were Muslims or non-Muslims, male or female. Their acceptance of the values of democracy was strengthened by the fact that the party leaders such as Hidayat Nur Wahid, Zulkieflimansyah and Tifatul Sembiring believed that democracy was the best way to achieve their political goals. They argue that, based on the reality of the political situation in Indonesia, there is no other way to be involved in the political arena except to follow democratic processes.

As discussed above, the commitment of PKS to strengthening democracy in Indonesia also could be seen in the process of recruiting their leaders. PKS has practiced democratic rules in their internal party activities, particularly in the way they recruited the members who would be nominated as parliamentary candidates and how they choose their own leaders. The style of member training and the existence of the

Rakyat/DPR (People's Representative Council), Mahkamah Agung/MA (the Supreme Court), and Mahkamah Konstitusi/MK (the Constitutional Court). In dealing with the President and Vice President, the MPR would be responsible for the inauguration ceremony and, should the occasion call for it, the impeachment of the President or Vice President, or both. The MPR would elect a President and Vice President only if both positions were vacant. See Tim Redaksi Kawan Pustaka, UUD 45 dan Perubahannya (Jakarta: Kawan Pustaka, 2006). 
Majlis Shura, could be regarded as a reflection of the fact that the party's internal structures are almost the same as their counterpart in Egypt. However, it is necessary to note that in terms of member recruitment and expanding the cadres of the party, the PKS seems to have a special strategy that is encouraging their cadres to have big families. Having a lot of children, as shown by parliament members from PKS, has been interpreted by Indonesians as a reflection of a party strategy to increase their party membership. Finally, the above discussion shows clearly that PKS not only believes that democracy is compatible with Islam but also it has practiced democratic rule in their internal party affairs, both in recruiting its members and leaders. 
PKS' Democratic Experiences in Recruiting Members and Leaders

\section{BIBLIOGHRAPHY}

Bastoni, Hepi Andi and Syaiful Anwar, Penjaga Nurani Dewan, Jakarta: Pustaka Al-Bustan, 2006.

Collins, Elizabeth Fuller, "Partai Keadilan Sejahtera (PKS): Justice and Welfare Party or Prosperous Justice Party," at http://www.ohiou.edu/pols / faculty/malley/collins3.html (accessed January 24, 2008).

---- and Ihsan Ali Fauzi, "Islam and Democracy!: The Successful New Party PKS is a Moderate Alternative to Radical Islamism," Inside Indonesia, Jan-March 2005.

Damanik, Ali Said, Fenomena Partai Keadilan: Transformasi 20 Tahun Gerakan Tarbiyah di Indonesia, Jakarta: Teraju, 2002.

Djalal, Dini, "Indonesia’s Powerful Student Movement Divided," Far Eastern Economic Review, March 22, 2001.

DPP Partai Keadilan Sejahtera, Manajemen Tarbiyah Anggota Pemula, Jakarta: Syaamil Cipta Media, 2004.

----, Sekilas Partai Keadilan Sejabtera, Jakarta: 1998.

Furkon, Aay Muhamad, Partai Keadilan Sejabtera: Ideologi dan Praksis Politik Kaum Muda Muslim Indonesia Kontemporer, Jakarta: Teraju, 2004.

Hibban, Ibnu, Shabib Ibnu Hibban: Chapter Marriage, No. 4028.

Machmudi, Yon, Partai Keadilan Sejabtera: Wajah Baru Islam Politik Indonesia, Bandung: Harakatuna, 2005.

Rosyad, Rifki, A Quest for True Islam: A Study of Islamic Resurgence Movement Among the Youth in Bandung, Indonesia, Canberra: Australian University Press, 2006.

Sekretariat Jenderal DPP PKS Bidang Arsip dan Sejarah, Sikap Kami: Kumpulan Sikap Dakwah Politik PK dan PKS Periode 1998-2005, Bandung: Harakatuna Publishing, 2007.

Tim Redaksi Kawan Pustaka, UUD 45 dan Perubabannya, Jakarta: Kawan Pustaka, 2006.

Wahid, Hidayat Nur, "Islam, Democracy and Politics in Indonesia," The Jakarta Post, September 9, 2005.

----, “Power Means Serving Others," Van Zorge Report, March 18, 2002. 
Waluyo, Sapto, Kebangkitan Politik Dakwah: Konsep dan Praktik Politik Partai Keadilan Sejabtera di Masa Transisi, Bandung: Harakatuna, 2005.

Zulkieflimansyah, "Overcoming the Fear: PKS and Democratization," The Jakarta Post, December 13, 2005.

----, "Prospects for the Justice and Prosperity Party (PKS) and Political Islam," USINDO Open Forum, Washington DC, June 8, 2006. 